\title{
Diminished Type I Collagen Synthesis and Reduced Alpha 1(I) Collagen Messenger RNA in Cultured Fibroblasts from Patients with Dominantly Inherited (Type I) Osteogenesis Imperfecta
}

\author{
D. W. Rowe, J. R. Shapiro, M. Poirier, and S. Schlesinger \\ Department of Pediatrics, University of Connecticut Health Center, Farmington, Connecticut 06032; Pratt Diagnostic Clinic, \\ Tufts University School of Medicine, Boston, Massachusetts 02111; and Medical Genetics Program Clinical Center, \\ National Institutes of Health, Bethesda, Maryland 20205
}

\begin{abstract}
Type I osteogenesis imperfecta (OI) is characterized clinically by a moderate fracture frequency with minimal bone deformity and dominant inheritance. Previous studies of the collagenous proteins synthesized by dermal fibroblasts obtained from unrelated patients with this form of $O I$ suggested that the biochemical basis of the disease was reduced production of type I collagen. This study was designed to determine if this biochemical finding segregated with the disease within an individual family. Dermal fibroblast strains were established from three generations of a family having the typical features of type I OI. Analysis of the collagenous proteins made in culture revealed an elevated $\alpha$ (III) to $\alpha 1$ (I) collagen type ratio and an elevated $\alpha 1(I)$ to $\alpha 2$ (I) collagen chain ratio. The procollagen that accumulated in the medium reflected these ratios to the same degree. Total collagen synthesis was significantly reduced in affected family members. Therefore, the most striking abnormality in affected members was a 50-75\% reduction of type I collagen production. Furthermore, the ratio of the $\alpha 1(I) / \alpha 2(I)$ collagen messenger RNA (mRNA), measured by dot hybridization, was one-half of the value of uninvolved family members and unrelated controls. Since the reduction in the production of type I collagen and the altered $\alpha 1(I) / \alpha 2(I)$ mRNA ratio clearly segregated with affected individuals within this family, these biochemical measurements may be a useful genetic marker for type I OI.
\end{abstract}

\section{Introduction}

Osteogenesis imperfecta (OI) ${ }^{1}$ is a heritable disease of connective tissue with the unifying feature of recurrent bone fractures. The classification proposed by Sillence (1) has been an impor-

This work was presented at the Society for Pediatric Research, Washington, DC, May 1983; and was published in abstract form, 1983, Pediatr. Res. 17:218a.

Dr. Rowe is a recipient of Research Career Development Award HD00330.

Received for publication 23 May 1984 and in revised form 25 March 1985.

1. Abbreviations used in this paper: cDNA, complementary DNA; HLA, human leukocyte antigen; mRNA, messenger RNA; OI, osteogenesis imperfecta; SSC, sodium chloride/trisodium citrate.

J. Clin. Invest.

(c) The American Society for Clinical Investigation, Inc.

0021-9738/85/08/0604/08 $\$ 1.00$

Volume 76, August 1985, 604-611 tant contribution to sorting out the clinical heterogeneity of OI. Using this classification, the milder forms of the disease (previously called OI tarda) are identified as either type I or IV. Patients in the type I category have dominantly inherited mild disease with blue sclera and minimal bone deformity. We have recently proposed that an additional criteria for this diagnosis is the production of a reduced quantity of type I collagen (2). This criteria was added to make type I patients readily identifiable by clinical and biochemical criteria. Furthermore, it differentiates type I patients from other patients with mild to moderate disease and dominant or sporadic occurrence in whom there is evidence of a structural abnormality in type I collagen. Thus, patients in the latter group (type IV) represent a heterogeneous group that seems to have a fundamentally different biochemical defect than those patients categorized as type $\mathbf{I}$.

If the biochemical marker that we believe reflects the underlying molecular defect of type I OI has value as a genetic marker for this disorder, then the biochemical abnormality should segregate with affected members in a family with dominant inheritance of the disease. Thus, we undertook to study a large pedigree in which the propositus had the biochemical and clinical features of type I OI. We have also measured the ratio of $\alpha 1(\mathrm{I}) / \alpha 2$ (I) collagen messenger RNA (mRNA) in these family members. The results show a distinct segregation of biochemical abnormalities with the disease; however, there does appear to be a graded spectrum of clinical severity of the disease that is not readily explained by the biochemical defects.

\section{Methods}

Patient studies. The propositus is a 47-yr-old male with OI and Paget's disease (III-28; fig. 1). He was extensively studied at the Clinical Center of the National Institutes of Health and is the subject of a report noting the familial occurrence of OI and Paget's disease (3). Other family members affected with OI (IV-18, V-7, and V-8) plus an unaffected fraternal twin of the propositus (III-29) were also studied at the National Institutes of Health. Besides having a wide range of studies of blood chemistry, human leukocyte antigen (HLA), and blood group testing, they also were evaluated by audiology and ophthalmology. We examined the remainder of the pedigree at the University of Rochester. In all cases, a history and physical examination was obtained with particular attention to the fracture history, joint instability, auditory problems, and fertility. The physical examination focused on the musculoskeletal system, noting scoliosis or bone deformity, hyperextensibility, skin texture and thickness, eye color, and stature (Table I). In all instances, the patients underwent dermal skin biopsy from the inner aspect of the upper arm, which was used to initiate skin fibroblast cultures. For nonfamilial control samples, biopsies 
were obtained from a wide range of individuals who did not have clinical abnormalities of connective tissue or bone (2).

Biochemical studies. The skin fibroblasts were grown in Dulbecco's minimal essential medium containing $10 \%$ horse serum, nonessential amino acids, $100 \mu \mathrm{U} / \mathrm{ml}$ penicillin, and $100 \mu \mathrm{g} / \mathrm{ml}$ streptomycin in a humidified incubator containing $9 \% \mathrm{CO}_{2}$. The procedures for cell growth, radiolabeling of cell and medium proteins, and an analysis of collagenous proteins have been detailed in a previous publication (4). All studies were performed on cells between the fifth and tenth passage number so that in vitro aging effects would not alter the proportion of the two collagen types. To initiate the collagen studies, replicate petri dishes were seeded at a density of 5,000 cells $/ \mathrm{cm}^{2}$ and grown for $\sim 5-$ $7 \mathrm{~d}$ until visual confluency was observed. Under these conditions the cells have exited the log phase of growth but are still undergoing postconfluent cell division. At this point the medium was changed to one lacking nonessential amino acids and containing 5\% dialyzed fetal calf serum, $25 \mu \mathrm{g} / \mathrm{ml}$ of ascorbic acid, and $10 \mu \mathrm{Ci} / \mathrm{ml}$ of $\left[5-{ }^{3} \mathrm{H}\right]-\mathrm{L}$ proline. The cells were incubated in this mixture for 6 or $24 \mathrm{~h}$ for determination of total collagen synthesis or analysis of collagen and procollagen chains, respectively.

Total collagen production was determined on three separate 60$\mathrm{mm}$ petri plates using the collagenase digestion procedure of Peterkofsky and Diegelmann (5) using the factor of 5.4 to correct for the enrichment of proline in collagen relative to noncollagen proteins. For this analysis, the medium was removed from the cell layer and the cell layer was mechanically detached from the petri dish. The cells were homogenized in $1 \mathrm{M} \mathrm{NaCl}, 0.05 \mathrm{M}$ Tris, $\mathrm{pH} 7.5$, containing $20 \mathrm{mM}$ EDTA, 0.3 $\mathrm{mM}$ phenylmethylsulfonyl fluoride, and $10 \mathrm{mM}$ EDTA using a Brinkmann polytron (Brinkmann Instruments Co., Westbury, NY). After the cell debris was removed by centrifugation at $15,000 \mathrm{~g}$, the cell supernatant and medium protein was recombined. The proteins were precipitated in 15\% TCA, washed twice with 5\% TCA, resolubilized in $0.1 \mathrm{M} \mathrm{NaOH}$, neutralized, and incubated with purified bacterial collagenase.

The relative content of types I and III collagen was obtained after limited pepsin digestion of the combined medium and cell layer proteins of three pooled $60-\mathrm{mm}$ petri plates (6). The TCA-precipitated proteins were redissolved in $0.5 \mathrm{M}$ acetic acid (HAc) previously adjusted to $\mathrm{pH} 2.0$ with $\mathrm{HCl}$. Pepsin was added to a concentration of $1.0 \mathrm{mg} / \mathrm{ml}$ and the solution was incubated for $2 \mathrm{~h}$ at $15^{\circ} \mathrm{C}$. We have previously shown that under these conditions pepsin does not preferentially degrade the $\alpha$-chain of either collagen type (4). The reaction was terminated by adding $50 \mu \mathrm{g} / \mathrm{ml}$ of carrier collagen and $\mathrm{NaCl}$ to $0.85 \mathrm{M}$. After $4 \mathrm{~h}$ at $4^{\circ} \mathrm{C}$, the precipitated proteins were collected by centrifugation at $17,000 \mathrm{~g}$ for $10 \mathrm{~min}$, washed once with $3.5 \mathrm{M} \mathrm{NaCl}$, $0.05 \mathrm{M}$ Tris, pH 7.5, followed by $18 \%$ ethanol. The air-dried precipitate was redissolved in SDS electrophoresis buffer and the types I and III bands were separated on a 7\% SDS acrylamide gel using the interrupted reduction technique of Sykes et al. (7). The medium procollagens were precipitated by adjusting the solution to $30 \%$ ammonium sulfate for $10-12 \mathrm{~h}$ at $4^{\circ} \mathrm{C}$. The precipitate was collected by centrifugation at

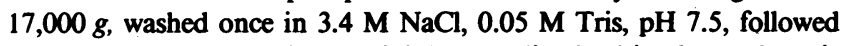
by $18 \%$ ethanol. The dried precipitate was dissolved in electrophoresis buffer and the procollagen chains were separated by electrophoresis in $5 \%$ SDS acrylamide gels (8). The radioactive bands were identified by fluorography (9) and the relative density of each band was assessed with a Transidyne densitometer (Transidyne General Corp., Ann Arbor, MI). The tracings were made within the linear range of the instrument and were expressed in arbitrary units. No correction was made for the small difference in proline content between types I and III collagen.

The production of type I and type III collagen, expressed as a percentage of total cell protein, assumed that only these two collagens were made by the fibroblast. Type $\mathrm{V}$ collagen, which occasionally was seen on the acrylamide gels, was never $>5 \%$ of the total collagen. The collagen was expressed as a percentage of total protein production to avoid potential differences in the proline pools among the various cell strains. Thus type I collagen was calculated as total collagen production (expressed as $\%$ of total protein production)/[1 + ratio of $\alpha 1(\mathrm{III}) / \alpha 1(\mathrm{I})]$. The data is presented as the mean $\pm 1 \mathrm{SD}$, using the Student's $t$ test for statistical comparisons.

Total RNA was extracted from six $100-\mathrm{mm}$ plates that had been used for harvesting media for procollagen analysis. After the plates were washed with phosphate-buffered saline (PBS), the cells were harvested in $10 \mathrm{ml}$ of $10 \% \mathrm{SDS}, 0.05 \mathrm{M}$ Tris, $\mathrm{pH} 7.5$, and $1 \mathrm{mM}$ EDTA containing $50 \mu \mathrm{g} / \mathrm{ml}$ of proteinase $\mathrm{K}$. The solution was Dounce homogenized, incubated $1 \mathrm{~h}$ at $37^{\circ} \mathrm{C}$, and then extracted in an equal volume of phenol/chloroform. Total nucleic acids were precipitated at $-20^{\circ} \mathrm{C}$ overnight in $2 \mathrm{vol}$ of ethanol, collected by centrifugation at $17,000 \mathrm{~g}$ for $10 \mathrm{~min}$, and redissolved in $1 \mathrm{ml}$ of $6 \mathrm{M}$ guanidine. RNA was precipitated by addition of $0.5 \mathrm{ml}$ of ethanol at $-20^{\circ} \mathrm{C}$ for a minimum of $3 \mathrm{~h}$, washed once in $4 \mathrm{M}$ guanidine, 33\% ethanol, washed twice in $80 \%$ ethanol, dried, and redissolved in $200 \mu \mathrm{l}$ of $10 \mathrm{mM}$ Tris, pH 7.5, 1 mM EDTA (10).

To measure the relative collagen mRNA content in the total RNA, a 4- $\mu$ g aliquot was serially diluted in $20 \times$ sodium chloride/trisodium citrate (SSC) $(1 \times$ is $0.15 \mathrm{M} \mathrm{NaCl}, 0.015 \mathrm{M}$ trisodium citrate) in a microtiter plate over a range of $2-0.125 \mu \mathrm{g}$. The RNA content was adjusted to $2 \mu \mathrm{g}$ in all wells by addition of Escherichia coli transfer RNA. The final volume was $200 \mu \mathrm{l}$ and the lowest concentration of SSC in any of the dilutions was $15 \times$. The dilutions were done in duplicate (for $\alpha 1(\mathrm{I})$ and $\alpha 2(\mathrm{I})$ ) and eight samples were diluted at a time with the aid of an eight-member microtiter pipettor (Titertec; Flow Laboratories, Inc., McLean, VA). This apparatus helped ease this procedure and significantly reduced the pipetting error.

The diluted RNA was applied to a manifold (Schleicher \& Schuell, Inc., Keane, NH) containing a nitrocellulose membrane (Millipore HA45; Millipore/Continental Water Systems, Bedford, MA) overlying one sheet of Whatman 3-mm paper (Whatman, Inc., Clifford, NJ) (11). Both sheets had been wetted in water and then equilibrated in 20X SSC. A vacuum was applied to the manifold after the RNA solution was transferred. The nitrocellulose was baked at $75^{\circ} \mathrm{C}$ for $2 \mathrm{~h}$ and then incubated at $42^{\circ} \mathrm{C}$ for $3 \mathrm{~h}$ in a prehybridization buffer containing $50 \%$ formamide, $50 \mathrm{mM} \mathrm{NaHPO}, \mathrm{pH} 6.5,5 \times \mathrm{SSC}, 5 \times$ Denhardts, and $250 \mu \mathrm{g} / \mathrm{ml}$ of single stranded DNA from salmon sperm. The solution was changed to a similar one also containing $10 \%$ dextran sulfate and $5 \times 10^{6} \mathrm{cpm}$ per filter of ${ }^{32} \mathrm{P}$-labeled complementary DNA (cDNA) probe. The filters were incubated $12-16 \mathrm{~h}$ at $42^{\circ} \mathrm{C}$, washed $4 \times$ in a solution of $0.1 \times$ SSC and $0.1 \%$ SDS at room temperature, and air dried. The radioactive filter was exposed to Royal X-Omat film (Eastman Kodak Co., Rochester, NY) at $-70^{\circ} \mathrm{C}$ for $1-$ $4 \mathrm{~d}$ with an intensifying screen. After the film was developed, the spots on the film were quantitated using a Transidyne densitometer (Transidyne General Corp., Teledyne Instruments, Inc., City of Industry, CA). The density of the five RNA dilutions was plotted against the quantity of fibroblast RNA applied to each well and the slope of the linear region of the curve was calculated. The ratio of $\alpha 1(\mathrm{I}) / \alpha 2(\mathrm{I})$ of the unknown RNA was calculated by relating it to the same ratio of a control RNA whose value was set at two (12).

The cDNA probes to $\alpha 1(\mathrm{I})$ and $\alpha 2(\mathrm{I})$ human collagen mRNA were obtained from F. Ramirez of Rutgers University (13, 14): Hf404 $(\alpha 1[\mathrm{I}])$ and $\mathrm{Hf} 32(\alpha 2[\mathrm{I}])$. The plasmids were grown in E. coli $\mathrm{Hb} 101$ cells. The inserted DNA was removed from the plasmid DNA by Eco R1 (HF404) or Pvu II/Eco R1 (Hf32) digestion on 1\% agarose and transblotted onto DEAE paper (15). The DNA was radiolabeled with $\left.{ }^{32} \mathrm{P}\right] \mathrm{dCTP}$ and $\left.{ }^{32} \mathrm{P}\right] \mathrm{dGTP}$ to a specific activity of $4-8 \times 10^{8} \mathrm{cpm} / \mu \mathrm{g}$ DNA using the DNA polymerase/DNAse solution supplied by Amersham Corp. (Arlington Heights, IL).

\section{Results}

The clinical characteristics of the family members are itemized in Table I. Those family members with unequivocal OI demonstrated numerous fractures that were more frequent before puberty, although in certain members, fractures in the postpubertal period were occasionally observed. Except for the 
Table I. Clinical Features of T Family

\begin{tabular}{|c|c|c|c|c|c|c|c|c|}
\hline ID Code & Sex & Age & Fracture & $\begin{array}{l}\text { Height } \\
\text { (percentile) }\end{array}$ & Eye color & Teeth & $\begin{array}{l}\text { Joint } \\
\text { hypermobility }\end{array}$ & Other \\
\hline & & $y r$ & No. & $\mathrm{cm}$ & & & & \\
\hline \multicolumn{9}{|l|}{ Affected } \\
\hline III-28 & $\mathbf{M}$ & 48 & 20 & $154(3)$ & B & Decay & + & Paget's disease \\
\hline III-5 & $\mathrm{F}$ & 49 & 16 & $152(5)$ & B & Decay & + & Mild scoliosis \\
\hline \multirow[t]{2}{*}{ III-26 } & F & 53 & 12 & $145(3)$ & B & Decay & n1 & \\
\hline & & & & & & & & Disk disease \\
\hline III-27 & F & 51 & 20 & $154(10)$ & $\dot{\mathbf{B}}$ & Decay & n1 & Mild scoliosis \\
\hline IV-18 & F & 32 & 20 & $162(50)$ & B & Decay & n1 & Obesity \\
\hline IV-21 & $\mathbf{F}$ & 21 & 10 & $158(25)$ & B & Decay & + & Pectus excavatum \\
\hline & & & & & & & & $\begin{array}{l}\text { Joint dislocation } \\
\text { Small for gestational }\end{array}$ \\
\hline V-7 & $\mathbf{F}$ & 11 & 12 & $150(3)$ & B & Decay & + & age \\
\hline V-8 & $\mathbf{F}$ & 11 & 2 & $162(50)$ & B & Decay & + & \\
\hline \multicolumn{9}{|c|}{ Unaffected } \\
\hline III-32 & $\mathbf{M}$ & 41 & 0 & $175(40)$ & W & Decay & n1 & Traumatic fracture (1) \\
\hline III-29 & $\mathbf{M}$ & 48 & 1 & $165(5)$ & W & Decay & $\mathrm{n} 1$ & Traumatic fracture (1) \\
\hline IV-15 & $\mathbf{F}$ & 27 & 1 & $168(80)$ & W & nl & nl & \\
\hline IV-14 & $\mathbf{F}$ & 29 & 0 & $157(15)$ & W & n1 & nl & \\
\hline
\end{tabular}

Abbreviations used in this table: $\mathrm{B}$, blue; $\mathrm{nl}$, normal; $\mathrm{W}$, white; + , present.

propositus, there was no evidence of long bone deformity and only a mild degree of scoliosis. There were various degrees of joint laxity. Blue sclera were observed in all affected members, although the intensity was quite variable. All the affected members had teeth that were subject to extensive decay but they did not have dentinogenesis imperfecta. Finally, many, but not all, of the affected family members had stature less than the 5th percentile.
There appeared to be a spectrum of disease severity within this family. Those most severely affected (III-28, III-26, III-5, and V-7) exhibited more severe short stature and a mild degree of scoliosis relative to those that were less severely affected (V8, IV-18, and IV-21). Most striking were two identical twins (V-7 and V-8), who were the offspring of a mildy affected mother (IV-18) (Fig. 1). Twin (V-8) was born small for gestational age, had a complicated neonatal course and keto-

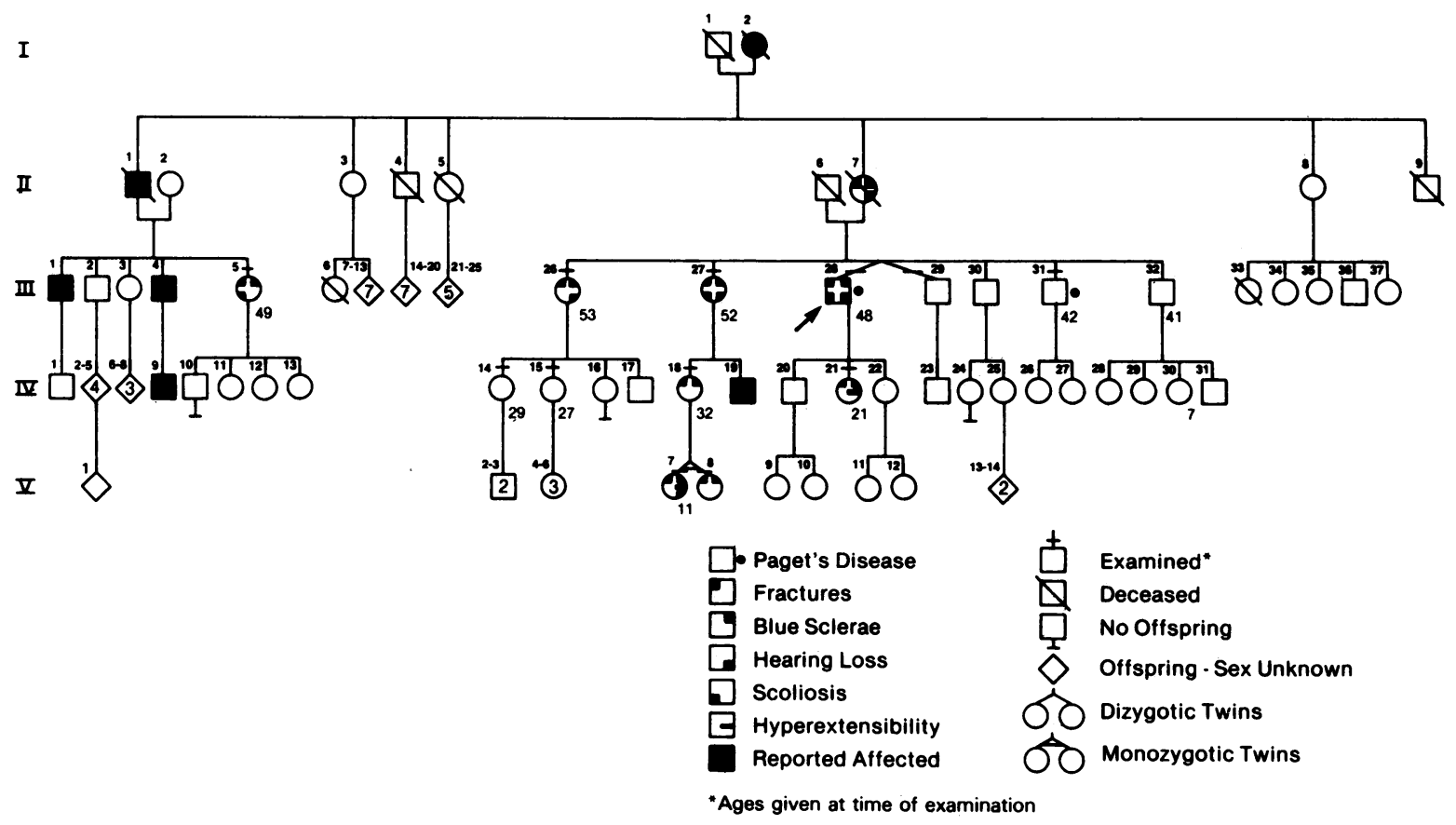

Figure 1. Pedigree of $\mathrm{T}$ family. The generation is identified by the roman numeral at the left of the figure and the individual family member is identified by the number above the pedigree symbol. The number within the symbol indicates the number of people in one family included, but not examined within a generation. The individuals that are the subject of this report are indicated by the symbols containing a number beneath them. This number is the subject's age at the time of the examination. Affected family members are indicated by the keyed clinical features, while the control individuals lack the keyed findings. The arrow points to the propositus of the pedigree. 
genic hypoglycemia in early childhood. She has had 12 fractures and her current height is $150 \mathrm{~cm}$ (3rd percentile). The twin was born appropriate for gestational age and has had only two fractures at age 8 and 9 secondary to strenuous exercise. Her current height is $162 \mathrm{~cm}$ (50th percentile). The twins were HLA and blood group identical. There was no linkage of the HLA haplotype and affected family members.

Dermal fibroblasts were radiolabeled with $\left[{ }^{3} \mathrm{H}\right]$ proline to study collagen synthesis from each family member. Typical bands of types I and III collagen and types I and III procollagen are illustrated on the fluorograms in Fig. $2 A$ and $B$. Even with visual inspection of the gels, the affected family members can be identified by the relative density of the type $\alpha 1$ (III)/ $\alpha 1$ (I) band. The migration rate of the collagen alpha chain and all the procollagen chains were identical in affected and unaffected family members. The ratio of $\alpha 1$ (III)/ $\alpha 1$ (I) (Fig. 3) in affected family members was significantly elevated relative to unaffected family members $(0.65 \pm 0.40$ vs. $0.19 \pm 0.03, P$ $<0.05$ ). The medium procollagens (pro $\alpha 1$ (III)/pro $\alpha 1(\mathrm{I})$ ) $\mathrm{dem}$ onstrate a similar ratio $(0.63 \pm 0.43$ vs. $0.22 \pm 0.05, P<0.05)$. As shown in Fig. 4, the ratio of the alpha chains of type I

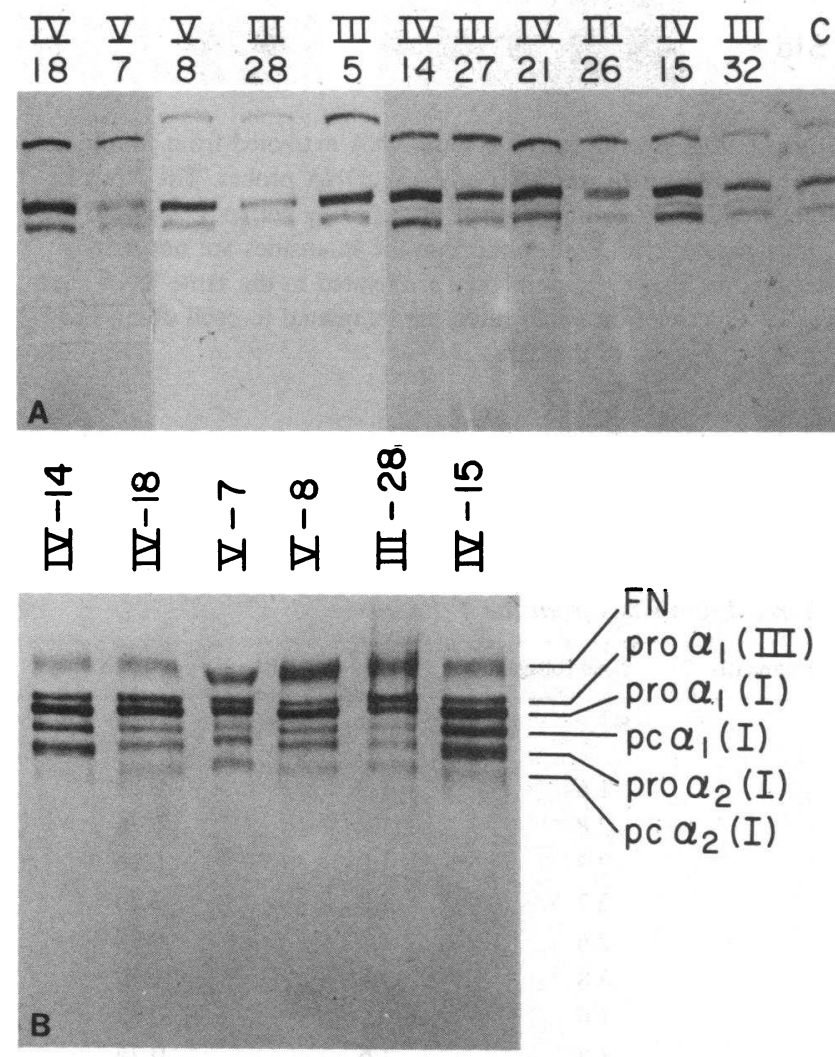

Figure 2. (A) Fluorogram of an interrupted 7\% SDS acrylamide gel of the combined medium and cell collagen chains after limited pepsin digestion. From the top of the figure, the radiolabeled bands are: alpha 1(III), alpha 1(I), and alpha 2(I). The relative intensity of each band was calculated from the densitometry tracing of the $x$-ray film. This composite photograph shows the specific gels that were used in the ratio calculation. Lane $C$ is collagen obtained from a nonfamily control cell strain. (B) Fluorogram of the procollagen chains that accumulate in the cell medium. To calculate the procollagen chain ratios, the densities of the bands of the partially converted procollagens were added. Thus, pro $\alpha 1(\mathrm{I})$ was the sum of $\operatorname{pro} \alpha \mathrm{I}(\mathrm{I})$ and pc $\alpha 1(\mathrm{I})$, while pro $\alpha 2(\mathrm{I})$ was the sum of pro $\alpha 2(\mathrm{I})$ and $\mathrm{pc} \alpha 2(\mathrm{I})$.

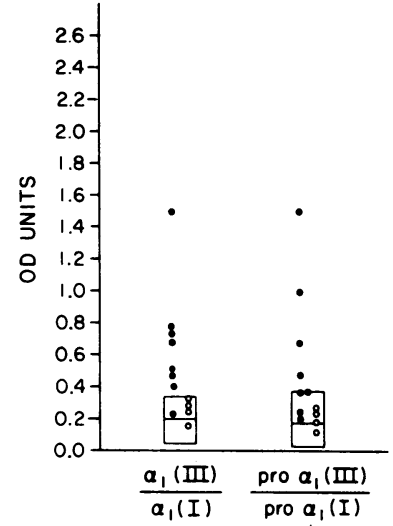

Figure 3. Ratio of relative OD units of the $\alpha 1$ (III) $/ \alpha 1$ (I) and pro $\alpha 1(\mathrm{III}) / \alpha 1$ (I) from each biopsied individual. (๑) Affected individual. (0) Unaffected family member. The midlines of the rectangles represent the mean, while the included areas on each side of the mean represent one standard deviation of 19 unrelated control individuals.

collagen $(\alpha 1(\mathrm{I}) / \alpha 2(\mathrm{I}))$ from affected members was also greater in the unaffected members $(2.80 \pm 0.48$ vs. $2.09 \pm 0.30, P<0.01)$. The type I procollagen chain ratio (pro $\alpha 1(\mathrm{I}) / \operatorname{pro} \alpha 2(\mathrm{I}))$ was also increased in affected family members $(2.67 \pm 0.32$ vs. $2.01 \pm 0.28$, $P<0.01$ ).

Total collagen synthesis expressed as a percentage of total protein synthesis (Fig. 5) was depressed in all affected members. The mean of affected members was $2.28 \pm 0.53$ while unaffected was $5.4 \pm 0.77(P<0.001)$. The most significant and consistent abnormality in affected family, members was the reduced production of type I collagen (1.44 \pm 0.42 vs. $4.52 \pm 0.54, P$ $<0.001$ ). The individual patient values for the collagen chain ratio and percent collagen synthesis are given in Table II.

The $\alpha 1(\mathrm{I}) / \alpha 2$ (I) collagen mRNA ratio was determined using a dot-hybridization procedure with cDNA probes specific for the $\alpha 1$ (I) or $\alpha 2$ (I) mRNA. The radiographs of this hybridization of mRNA from affected and unaffected family members are shown in Fig. 6 and representative curves obtained from densitometry tracings of the radiographs are illustrated in Fig. 7. The broken line is the computer-generated best fit for the linear portion of the test points. Points that are circled were omitted from the calculation. The solid line is the slope of the RNA standard. By relating the slope of the $\alpha 1(\mathrm{I})$ and $\alpha 2(\mathrm{I})$ density curve to the slope obtained on the standard RNA source, the $\alpha 1(\mathrm{I}) / \alpha 2$ (I) mRNA ratio can be calculated. This value is multiplied by two since the $\alpha 1$ (I) content in the cytoplasm is twice $\alpha 2(\mathrm{I})$. The calculations revealed that the ratios in affected members were reduced to less than half of that found in unaffected family members $(0.85 \pm 0.13$ vs. $2.22 \pm 0.23, P<0.001$; see Fig. 8). In most of the affected members, only the $\alpha 1$ (I) mRNA content was low. However, in $\mathrm{V} 7$ and V8 a reduction in both $\alpha 1$ (I) and $\alpha 2$ (I) was found, although the fall in $\alpha 1$ (I) exceeded the fall in $\alpha 2(\mathrm{I})$.

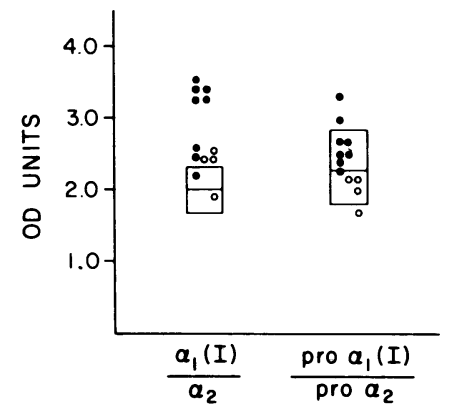

Figure 4. Ratio of $\alpha 1(\mathrm{I}) / \alpha 2$ and $\operatorname{pro} \alpha 1(\mathrm{I}) / \mathrm{pro} \alpha 2$ in affected and unaffected individuals. See Fig. 3 for legend key. 


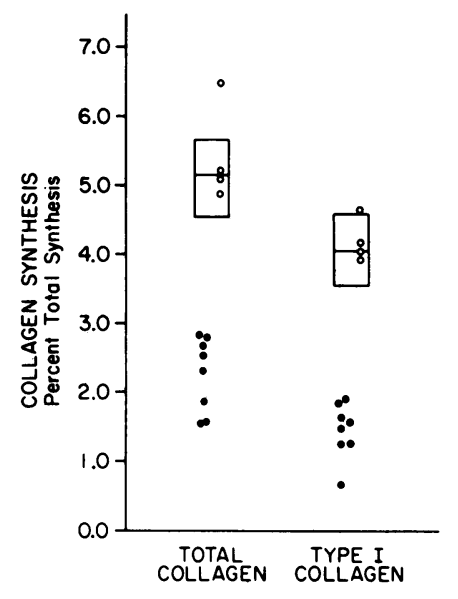

\section{Discussion}

Significant advances have been made in understanding the biosynthesis and structure of type I collagen $(16,17)$. Type I collagen, the major collagen of the connective tissues forming bone and tendons, is a heteropolymer composed of two $\alpha 1$ chains and one $\alpha 2$-chain. Each chain is synthesized as a 155,000-D precursor, assembled into a triple helical structure within the cell, secreted, and incorporated into the matrix through a series of modifying steps. Specific elements of the primary structure are required for a stable helix to function within the connective tissue.

Recent studies of OI have found abnormalities in certain aspects of the primary structure of type I collagen. For example, in neonatal lethal form of OI (type II), primary structural abnormalities of the $\alpha 1$ (I)-chain have been observed that impair secretion of those molecules that incorporate the abnormal chain (18-21). A patient, whom we have identified as type IV OI, has evidence for a structural abnormality of the $\alpha 2(\mathrm{I})$-chain $(2,22)$. One child with type III OI, the most severe nonlethal form, fails to incorporate the $\alpha 2$ (I)-chain into the
A

$$
\alpha_{1}(I)
$$

$$
\begin{aligned}
& \text { II }-14 \\
& \text { III }-32 \\
& \text { III }-26 \\
& \text { III }-27
\end{aligned}
$$$$
\text { IZ- } 15
$$
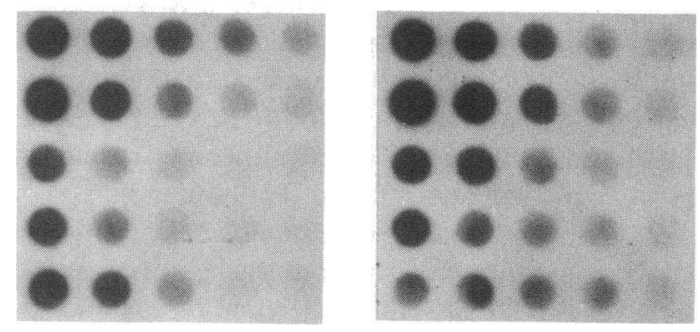

\section{B}
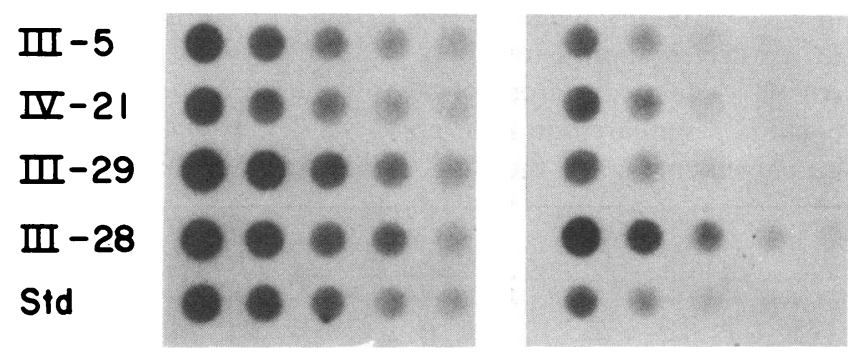

Figure 6. Dot hybridization of total RNA extracted from fibroblasts and hybridized with the $\alpha 1(\mathrm{I})$ or $\alpha 2$ (I) cDNA probes. The RNA is serially diluted to contain from 2 to $0.125 \mu \mathrm{g}$ per spot. $A$ and $B$ are from separate hybridizations so that the intensities are not strictly comparable. However, since they are related to the same RNA standard, the samples on either filter can be related to each other. See Fig. 7 for analysis of the data.

\begin{tabular}{|c|c|c|c|c|c|c|c|}
\hline ID Code & $\alpha 1(\mathrm{I}) / \alpha 2(\mathrm{I})$ & pro $\alpha 1(\mathrm{I}) / \operatorname{pro} \alpha 2(\mathrm{I})$ & $\alpha 1(\mathrm{III}) / \alpha 1(\mathrm{I})$ & pro $\alpha$ 1(III)/pro $\alpha$ 1(I) & Total collagen & Type I collagen & $\alpha 1(\mathrm{I}) / \alpha 2(\mathrm{I}) \mathrm{mRNA}$ \\
\hline Affected & & & & & $\%$ & $\%$ & \\
\hline III-28 & 3.3 & 2.5 & 0.30 & 1.54 & 1.6 & 1.2 & 0.88 \\
\hline III-5 & 3.2 & 2.7 & 0.48 & 0.38 & 2.8 & 1.9 & 0.76 \\
\hline III-26 & 2.6 & 3.0 & 0.75 & 0.33 & 2.3 & 1.3 & 0.96 \\
\hline III-27 & 3.3 & 2.3 & 0.75 & 0.36 & 2.7 & 1.5 & 0.76 \\
\hline IV-18 & 2.5 & 2.8 & 0.69 & 0.47 & 2.6 & 1.5 & 0.74 \\
\hline IV-21 & 3.3 & 2.4 & 0.51 & 0.99 & 2.8 & 1.9 & 1.10 \\
\hline V-7 & 2.2 & 2.4 & 1.50 & 0.60 & 1.6 & 0.6 & 0.82 \\
\hline V-8 & 3.5 & 3.2 & 0.21 & 0.31 & 1.8 & 1.6 & 0.76 \\
\hline Mean & 2.9 & 2.7 & 0.65 & 0.62 & 2.3 & 1.4 & 0.85 \\
\hline SD & \pm 0.48 & \pm 0.32 & \pm 0.40 & \pm 0.43 & \pm 0.53 & \pm 0.42 & \pm 0.13 \\
\hline$P$ & $<0.01$ & $<0.01$ & $<0.05$ & $<0.05$ & $<0.001$ & $<0.001$ & $<0.001$ \\
\hline \multicolumn{8}{|c|}{ Unaffected } \\
\hline III-32 & 1.9 & 1.6 & 0.17 & 0.25 & 5.1 & 4.3 & 2.48 \\
\hline III-29 & 1.9 & 2.2 & 0.18 & 0.16 & 4.7 & 4.0 & 2.04 \\
\hline IV-15 & 2.5 & 2.0 & 0.23 & 0.20 & 6.5 & 5.3 & 2.02 \\
\hline IV-14 & 2.1 & 2.2 & 0.19 & 0.27 & 5.3 & 4.5 & 2.34 \\
\hline Mean & 2.1 & 2.0 & 0.19 & 0.22 & 5.4 & 4.5 & 2.22 \\
\hline SD & \pm 0.30 & \pm 0.28 & \pm 0.03 & \pm 0.05 & \pm 0.77 & \pm 0.54 & \pm 0.23 \\
\hline
\end{tabular}

triple helix that leads to formation of type I collagen composed of three $\alpha 1$ (I)-chains $(23,24)$. However, current biochemical methodologies have not been successful in defining a structural

Table II. Analysis of Collagen Alpha Chains and Collagen mRNA in Cultured Fibroblasts from the T Family 


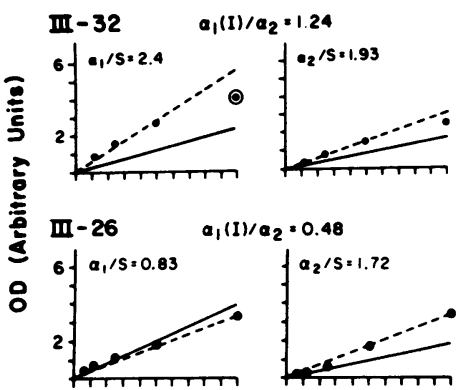

Figure 7. Analysis of the collagen mRNA by dot blot hybridization. A representative analysis from an affected (III-26) and unaffected (IV-14) family member is illustrated. The density of each dot is plotted against the total RNA applied $(2.0,1.0,0.5$, 0.125 , and $0.125 \mu \mathrm{g})$. The dashed line is the best fit to the linear region of the curve. Circled points represent data excluded from the calculation of the slope of the best fit line. The solid line is the best fit line for the RNA standard that was on the same nitrocellulose filter as the test samples. In both cases the best fit was defined as the line that included the origin and at least two other data points. Above each graph is given the ratio of the unknown RNA to the standard RNA. At the center and above each graph pair is the comparison of the $\alpha 1(\mathrm{I}) / \alpha 2(\mathrm{I})$ ratio of that sample. That value is multiplied by two when displayed in Fig. 8 and Table II.

mutation in type I collagen in most patients with these forms of OI.

Thus, the family described in this report stands out distinctly from other forms of $\mathrm{OI}$ by having dominant transmission of the disease, mild short stature, and a moderate fracture frequency with little tendency to bone deformity, except for mild scoliosis. Biochemically, as a group, they have a diminished production of type I collagen as judged by an elevated $\alpha$ 1(III)/ $\alpha 1$ (I)-chain ratio and low total collagen synthesis. Our initial studies of unrelated patients with clinical features of type I OI showed a normal $\alpha 1(\mathrm{I}) / \alpha 2(\mathrm{I})$-chain ratio (2). However, this ratio is elevated in this family, a finding that is unexplained. Thus, in this family, individuals with clinical findings of $\mathrm{OI}$ had low production of type I collagen and an elevated $\alpha 1(\mathrm{I}) /$ $\alpha 2$ (I)-chain ratio, while members that did not show clinical evidence of the disease had normal levels of type I collagen production and a normal $\alpha 1(\mathrm{I}) / \alpha 2$ (I)-chain ratio.

Thus, a consistent molecular mechanism for type I OI seems to be emerging. Barsh et al. (25) demonstrated low collagen synthesis and an intracellular $\alpha 1(\mathrm{I}) / \alpha 2$ (I)-chain ratio of $1: 1$ rather than $2: 1$. They suggested that the unbalanced intracellular $\alpha 1(\mathrm{I}) / \alpha 2(\mathrm{I})$-chain ratio is due to underproduction of the $\alpha 1$ (I)-chain, possibly secondary to a nonfunctional $\alpha 1$ (I) allele. In support of their data, our family showed an $\alpha 1(\mathrm{I}) /$ $\alpha 2$ (I) mRNA ratio in affected members that is half of the

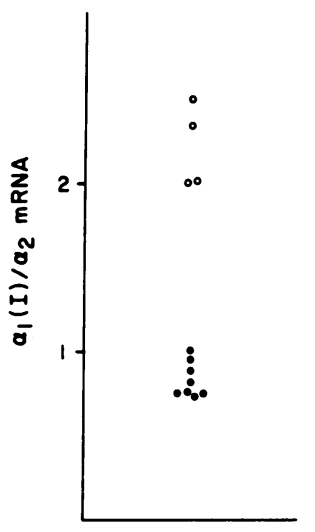

Figure 8. Ratio of collagen $\alpha 2(\mathrm{I}) / \alpha 2(\mathrm{I})$ mRNA in cultured fibroblasts. This ratio is obtained from the slopes of the curves as shown in Fig. 7. (॰) OI. (०) Family control. value found in the unaffected members. Since the reduced ratio was the result of a decrease in the $\alpha 1$ (I) mRNA content, the intracellular procollagen ratio of $1: 1$ can be explained by the low steady-state content of $\alpha 1$ (I) collagen mRNA. Even though the $\alpha 1(\mathrm{I}) / \alpha 2(\mathrm{I})$ ratio of the intracellular procollagen and collagen mRNA are both 1:1, the extracellular chain ratio is $2: 1$. This is due to the fact that type I collagen, having more than one $\alpha 2$-chain, is unstable (26). The unincorporated $\alpha 2$ chains are degraded intracellularly (25). The overall effect is a reduction in type I collagen production. The $\alpha 1$ (III)/ $\alpha 1$ (I)chain ratio is increased secondary to the fall in type I production rather than a compensatory increase in type III synthesis (2).

The molecular basis for the reduced $\alpha 1$ (I) mRNA content has yet to be determined. Unbalanced globin chain synthesis has been the hallmark for the $\alpha$ and $\beta$ thalassemias (27). In most of these diseases the reduced or absent synthesis of the $\alpha$-chain or $\beta$-chain is the result of deficient accumulation of the corresponding mRNA $(28,29)$. It is now realized that a wide range of molecular abnormalities are responsible for the reduced mRNA content (30-32). The most common abnormality seems to be an error of splicing that deletes a portion of an exon or fails to remove a region of an intron $(33,34)$. The $\alpha 1(\mathrm{I})$ collagen gene is present as one copy per haploid genome and is located on chromosome $17(12,35)$. The gene contains 51 exons that span a length of 18 kilobase pairs (36). Thus, it would not be surprising that an error of mRNA processing could occur that would affect the accumulation of the $\alpha$ l(I) mRNA from one of the two $\alpha 1$ (I) collagen alleles. The primary difference between the two diseases is that in $\beta$ thalassemia both alleles are affected while in type I OI only one abnormal allele results in clinical symptoms.

This work shows segregation of the biochemical measurement of diminished type I collagen production and the low $\alpha 1$ (I) mRNA level with the clinical diagnosis of type I OI in this family. Since we have made similar observations in individuals with type I OI unrelated to this family, this is evidence for a mutation of the $\alpha 1$ (I) collagen gene in this disease. A second approach to localizing the gene defect in type I OI is the use of restriction fragment length polymorphism within a large pedigree. However, polymorphisms linked to $\alpha 1$ (I) collagen gene have not yet been established. Recently, a linkage polymorphism of the $\alpha 2(I)$ collagen gene has been found. It was used to show linkage of OI to the $\alpha 2$ (I) gene in a family that would not be classified as type I (37). Using this polymorphism, it was not possible to show linkage in another large type I OI kindred in which cultured fibroblasts demonstrated the same biochemical abnormalities of collagen production as the family of this report (38). Thus, the lack of linkage to the $\alpha 2(\mathrm{I})$ allele is consistent with an $\alpha 1(\mathrm{I})$ gene defect in type I OI.

This family study suggests that the severity of the disease is roughly correlated with the reduction in type I collagen synthesis. The severity of OI was related to stature rather than to the number of fractures as a result of the difficulty of assessing physical activity. This was most dramatically illustrated in the identical twins, one of whom has moderately severe OI and the other who is only minimally affected. The poorer growth of the more severely affected twin (V-7) may be a reflection of the OI. Other observers have reported an association of small birth size with OI (39). Another interpretation 
would be that the small birth size was a result of intrauterine growth restraint associated with twinning. If the correlation between the severity of the biochemical abnormality and clinical disease is seen in other families of this type of OI, then this type of biochemical analysis may have value in predicting disease severity. The measurement will also be useful in determining affected individuals in a family in which there is a wide degree of disease severity. Patterson recently pointed out that women may have a very mild fracture history in childhood, only to develop significant osteopenia and fractures in the postmenopausal period (40).

Variability of expression of dominantly inherited disease within families and even between identical twins is well described $(41,42)$. Factors such as modifying genes, $X$ chromosome inactivation, and somatic cell selection have been postulated to explain this variability. If type $\mathrm{I} O \mathrm{OI}$ is due to a single defect within the $\alpha 1$ (I) collagen gene, then further study of those factors that modify the expression of the abnormal gene may provide rationale for treatment of this form of $\mathrm{OI}$ and possibly other diseases of bone formation.

\section{Acknowledgments}

This work was supported by grants from the March of Dimes (6-312), Osteogenesis Imperfecta Foundation, and the National Institutes of Health (AM30426).

\section{References}

1. Sillence, D. 1981. Osteogenesis imperfecta. An expanding panorama of variants. Clin. Orthop. Relat. Res. 159:11-25.

2. Rowe, D. W., M. Poirier, and J. R. Shapiro. 1981. Type I collagen in osteogenesis imperfecta: a genetic probe to study type I collagen biosynthesis. In The Chemistry and Biology of Mineralized Connective Tissues. A. Veis, editor. Elsevier North-Holland, Inc., New York. 155-162.

3. Shapiro, J. R., T. Triche, D. W. Rowe, A. Munati, H. S. Cattell, and S. Schlesinger. 1983. Osteogenesis imperfecta and Paget disease of bone: biochemical and morphologic studies. Arch. Intern. Med. 143: 2250-2257.

4. Rowe, D. W., and J. R. Shapiro. 1982. Biochemical features of cultured skin fibroblasts from patients with osteogenesis imperfecta. In Heritable Disorders of Connective Tissue. W. Akeson, P. Bornstein, and M. Glimcher, editors. C. V. Mosby, Co., St. Louis, MO. 269-282.

5. Peterkofsky, B., and D. Diegelmann. 1971. Use of a mixture of proteinase-free collagenase for the specific assay of radioactive collagen in the presence of other proteins. Biochemistry. 6:988-994.

6. Chung, E., and E. J. Miller. 1974. Collagen polymorphism: characterization of molecules with the chain composition $\alpha 1(\mathrm{III})_{3}$ in human tissue. Science (Wash. DC). 183:1200-1201.

7. Sykes, B., B. Puddle, M. Francis, and R. Smith. 1976. The estimation of two collagens from human dermis by interrupted gel electrophoresis. Biochem. Biophys. Res. Commun. 72:1472-1480.

8. Tanzer, M. L., R. L. Church, J. A. Yeager, E. Wampler, and E. D. Park. 1974. Procollagen: intermediate forms containing several types of peptide chains and non-collagen peptide extensions at $\mathrm{NH} 2$ and $\mathrm{COOH}$ ends. Proc. Natl. Acad. Sci. USA. 71:3009-3013.

9. Bonner, W. M., and A. R. Laskey. 1974. A film detection method of tritium-labelled proteins and nucleic acids in polyacrylamide gels. Eur. J. Biochem. 46:83-99.

10. Rowe, D. W., and B. E. Kream. 1982. Regulation of collagen synthesis in fetal rat calvaria by 1,25 dihydroxyvitamin $D_{3}$. J. Biol. Chem. 257:8009-8015.

11. Thomas, P. S. 1980. Hybridization of denatured RNA and small DNA fragments transferred to nitrocellulose. Proc. Natl. Acad. Sci. USA. 77:5201-5205.

12. DeWitt, W. J., M.-L. Chu, and D. J. Prockop. 1983. The mRNA for the pro $\alpha 1(\mathrm{I})$ and pro $\alpha 2(\mathrm{I})$ chains of type I procollagen are translated at the same rate in normal human fibroblasts from two variants of osteogenesis imperfecta. J. Biol. Chem. 258:14385-14389.

13. Chu, M.-L., J. C. Myers, M. P. Bernard, J. L. Ding, and F. Ramierz. 1982. Cloning and characterization of five overlapping cDNAs specific for the human proal(I) collagen chain. Nucleic Acid. Res. 10: 5925-5932.

14. Bernard, M. P., J. C. Myers, M.-L. Chu, F. Ramirez, E. F. Eikenberry, and D. J. Prockop. 1983. Structure of a cDNA for the pro 2 chain of human type I procollagen. Biochemistry. 22:11391145.

15. Danner, D. B. 1982. Recovery of DNA fragments from gels by transfer to DEAE-paper in an electrophoresis chamber. Anal. Biochem. 125:139-142.

16. Bornstein, P., and W. Traub. 1979. The chemistry and biology of collagen. In The Proteins. Vol. IV. H. Nuerath and R. L. Hill, editors. Academic Press, Inc., New York. 411-632.

17. Bornstein, P., and A. Sage. 1980. Structurally distinct collagen types. Annu. Rev. Biochem. 49:957-1003.

18. Barsh, G. S., and P. H. Byers. 1981. Reduced secretion of structurally abnormal type I procollagen in a form of osteogenesis imperfecta. Proc. Natl. Acad. Sci. USA. 78:5142-5146.

19. Williams, C. J., and D. J. Prockop. 1983. Synthesis and processing of a type I procollagen containing shortened pro $\alpha 1$ chains by fibroblasts from a patient with osteogenesis imperfecta. J. Biol. Chem. 258:5915-5921.

20. Chu, M.-L., C. J. Williams, G. Pepe, J. Hirsch, D. J. Prockop, and F. Ramierz. 1983. Internal deletion in a collagen gene in a perinatal lethal form of osteogenesis imperfecta. Nature (Lond.). 304: 78-80.

21. DeWet, W. J., T. Pihlajaniemi, J. Myers, T. Kelly, and D. J. Prockop. 1983. Synthesis of a shortened proa2(I) chain and decreased synthesis of pro 2 (I) chains in a proband with osteogenesis imperfecta. J. Biol. Chem. 258:7721-7728.

22. Byers, P., J. R. Shapiro, D. W. Rowe, K. Holbrook, and K. E. David. 1983. An abnormal $\alpha 2$ chain in type I collagen from a patient with a form of osteogenesis imperfecta. J. Clin. Invest. 78:689-697.

23. Nicholls, A. C., F. M. Pope, and H. Schloom. 1979. Biochemical heterogeneity of osteogenesis imperfecta: new variant. Lancet. I:1193.

24. Deak, S. B., A. Nicholls, M. Pope, and D. J. Prockop. 1983. The molecular defect in a nonlethal variant of osteogenesis imperfecta. Synthesis of proa2(I) chains which are not incorporated into trimers of type I procollagen. J. Biol. Chem. 258:15192-15197.

25. Barsh, G. S., K. E. David, and P. H. Byers. 1982. Type I OI: a non-functional allele for pro $\alpha$ l(I) chains of type I procollagen. Proc. Natl. Acad. Sci. USA. 79:3838-3842.

26. Tkocz, C., and K. Kuhn. 1969. The formation of triple-helical collagen molecules from $\alpha 1$ or $\alpha 2$ polypeptide chains. Eur. J. Biochem. 1:454-462.

27. Weatherall, D. J., and J. B. Clegg. 1982. Thalassemia revisited. Cell. 29:7-9.

28. Fukumaki, Y., P. K. Ghosh, E. J. Benz, V. B. Reddy, P. Lebowitz, B. G. Forget, and S. M. Weissman. 1982. Abnormally spliced messenger RNA in erythyroid cells from patient with $\beta^{+}$ thalasemmia and monkey cells expressing a cloned $\beta^{+}$thalassemic gene. Cell. 28:585-593.

29. Benz, E. J., A. L. Scarpa, B. L. Tonkonow, H. A. Pearson, and A. K. Ritchey. 1981. Post-transcriptional defects in $\beta$-globin mRNA in $\beta$-thalassemia: abnormal accumulation of $\beta$-mRNA precursor sequences. J. Clin. Invest. 68:1529-1538. 
30. Pergolizzi, R., R. A. Spritz, S. Spense, M. Goossens, Y. Wai Kan, and A. Bank. 1981. Two cloned $\beta$-thalassemia genes are associated with amber mutations at codon 39. Nucleic Acids Res. 24:7065-7072.

31. Orkin, S. H., and S. C. Goff. 1981. Nonsense and frameshif mutations in $\beta^{0}$-thalassemia detected in cloned $\beta$-globin genes. J. Biol. Chem. 256:9782-9784.

32. Poncz, M., M. Ballantine, D. Solowiejczyk, I. Borak, E Schwartz, and S. Sunez. 1982. $\beta$-Thalassemia in a Kurdist Jew: single base changes in the TATA box. J. Biol. Chem. 257:5994-5996.

33. Treisman, R., J. Proudfoot, M. Shander, and T. Maniatis. 1982. A single-base change at a splice site in a $\beta^{0}$-thalassemic gene causes abnormal RNA splicing. Cell. 29:903-911.

34. Busslinger, M., N. Moschonas, and R. A. Flavell. 1981. $\beta^{+}$ thalassemia: aberrant splicing results from a single point mutation in an intron. Cell. 27:289-298.

35. Solomon, E., L. Hiorns, D. Sheer, and D. Rowe. 1984. Confirmation that the type I collagen gene on chromosome 17 is COLlal $(\alpha 1(\mathrm{I}))$, using a human genomic probe. Ann. Hum. Genet. 48: 39-42.

36. Chu, M.-L., W. DeWet, M. Bernard, T. F. Ding, M. Morabito, J. Myers, C. Williams, and F. Ramirez. 1984. Structure of the human proa 1(I) collagen gene: evolutionary conservation of functional domain. Nature (Lond.). 310:337-340.

37. Tsipouras, P., T. C. Myers, F. Ramirez, and D. J. Prockop. 1983. Restriction fragment length polymorphism associated with the proa2(I) gene of human type I procollagen. J. Clin. Invest. 72:12621267.

38. Tsipouras, P., A. L. Borresen, L. A. Dickson, K. Berg, D. J. Prockop, and F. Ramirez. 1984. Molecular heterogeneity in the mild autosomal dominant forms of osteogenesis imperfecta. Am. J. Hum. Genet. 36:1172-1179.

39. Wynne-Davis, R., and J. Gormley. 1981. Clinical and genetic patterns in osteogenesis imperfecta. Clin. Orthop. Relat. Res. 159:2635.

40. Patterson, C. R., S. McAllion, and R. Stellman. 1984. Osteogenesis imperfecta after the menopause. N. Engl. J. Med. 310:16941696.

41. Vogel, F., and A. Motulsky. 1979. Human Genetics. SpringerVerlag, Berlin. pp. 83-87.

42. Carey, J. C., J. M. Laub, and B. D. Hall. 1979. Penetrance and variability in neurofibromatosis: a genetic study of 60 families. Birth Defects. 15:271-281. 